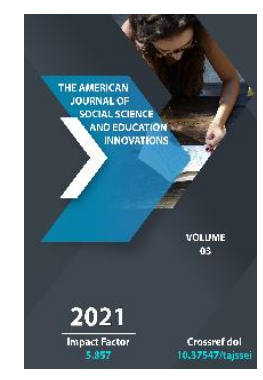

Journal Website: http://usajournalshub.c om/index,php/tajssei

Copyright: Original content from this work may be used under the terms of the creative commons attributes 4.0 licence.

\section{The Degree To Which A Person Feels Happy In The Family}

Sohibjamol Norkobilovna Jureva Candidate Of Psychological Sciences, Associate Professor Of Psychology And Pedagogy, Military-Technical Institute Of The National Guard Of The Republic Of Uzbekistan

Bogzoda Abdilkhakimovna Mamaradjabova

Teacher Of The Department Of Psychology, Termiz State University, Uzbekistan

\title{
ABSTRACT
}

This article defines illustrations of factors in foreign investigations which impact on personality happiness feeling, as well as psychological analysis of level ratio of adaptation on determining happiness.

\section{KEYWORDS}

Happiness, envy, euphoria, adaptation, mood, comparing, labour, child, health.

\section{INTRODUCTION}

Today, the issue of happiness in human and social life is studied not only at the level of one society or region, but also at the international level, and places among the countries of the world in terms of the level of happiness in their lives. It is based on certain general norms and requirements. In society, people are based on many factors that make up human life activities to determine the level of happiness of themselves, others and society. The most 
important of these are health, wealth, children, work, friends, and so on. In the example of these concepts, we consider the relativity of the perception of happiness and the degree of adaptation to it. The concept of happiness has its own specific relativity for everyone, and whether it is considered high or low depends on a number of factors regarding a person's outlook on life. The level of adaptation of each person to their own lifestyle plays a key role in this. In today's society, people care about themselves, others and the life of societyg There are a number of views on determining the level of happiness. Today, the development of society serves to increase the chances of a person feeling happy.

\section{METHODOLOGY}

The goals and objectives of the study are to study the psychoanalytic approach from the definition and interpretation of relative happiness relative to the degree of adaptation in determining happiness, to analyze the direct relationship between consciousness and unconsciousness of the individual from a psychoanalytic point of view. The characteristics of a person's sense of happiness - volitional qualities, emotional aspects are also required to be studied. It is also necessary to have a clearer idea of the nature of the process of feeling happiness, its laws and stages. Coverage of these issues also sets new tasks for this topic.

\section{METHODOLOGICAL BASIS OF THE RESEARCH}

From the classical approaches to the psychoanalytic interpretation of the author's personality in the science of happiness psychology Z. Freud, A. We know the scientific works of Adler, E. Fromm, LS Vygotsky, E. Gaziev. In recent years, as a result of the integration of sciences, this topic has been covered in the scientific work of philosophers, historians and literary scholars.

Studies have shown that a high level of happiness and satisfaction with one's life is often found in godly people, high spirituality, high faith,ideological immunity is characteristic of individuals who are strong, masters of their profession, highly satisfied with their profession, income, working conditions, balance of work and leisure.

Feelings of health-related happiness are associated with a person's health, well-being, well-being, well-being, well-being, well-being, well-being, well-being, well-being, well-being, well-being, well-being, well-being, well-being, well-being.n dependent. According to the degree of adaptation of a person to such situations, his level of satisfaction with life and feeling of happiness is formed. It can be seen that in different situations and situations, this feeling can undergo certain relative changes.

Special studies conducted by foreign psychologists on 128 paralyzed students showed that most of them wanted to commit cuitsid. Being physically deficient means living in a state of frustration with a body that does not obey you day by day. Yet there is after a year - only more than $10 \%$ thought their quality of life was bad, and many thought it was good or excellent. The 223 ambulance staff have been in this situation for yearswhen imagining how they might feel afterwards, only 39\% of them were angry; self-satisfaction; estimated that it was possible. But $95 \%$ of real patients feel this way, and $98 \%$ agree that they are a worthy person [1].

People tend to overestimate the long-lasting emotional consequences of very bad news. 
The sensitivity of brightly expressed positive events is also temporary. In euphoria, with winning the lotteryr usually find that the state of happiness does not change.

The feeling of happiness associated with wealth is associated with material wealth in a person's life, opportunities to increase or decrease needs, middle status, low income, inadequacies. The basic principle is to achieve and maintain the level of material needs.

The results of scientific research show that it is more difficult to achieve leisure than wealth. Many people think that I would feel happier when I had more money. So be itit is also possible, but this is only temporary, and the growth of wealth in the long run has little effect on happiness. In many rich countries, rich people are less fortunate than people who have only enough money to support themselves. Wealth is like health: its absence causes suffering, and its existence does not guarantee happiness. While most people agree that happiness cannot be bought with money, they believe that a large amount of money makes them determined, content, and happy. Well fullv As our checks increase, will our happiness increase over time? No, it will not increase. In the last forty years, the purchasing power of the average American citizen has doubled. In 1957, the average per capita income was \$9,000, equivalent to the 1995 dollar equivalent; By 1996, as the rich became richer and women's employment increased, the income was almost $\$ 20,000$. It has doubled, with the help of which the population has twice as many cars and many per capitahas this wealth, which allows you to buy color TVs, VCRs, personal computers, air conditioners, made it possible to buy a lot of happiness? The average American is twice as rich now, but not happier.In 1957, about 35 percent said they were; very happy; and in 1996 it was 30 percent. Indeed, given the doubling of divorces, the threefold increase in adolescent misbehavior, the fivefold increase in crime, and the increase in depression, modern Americans often seem unhappy. The situation is similar in Japan and European countries: where people eat better, have better health care, education and science, andthey are in some ways happier than people living in very poor countries. However, an increase in real income does not lead to an increase in happiness either. Such examples are not in favor of materialism: economic growth in rich countries has not led to an increase in moral and social well-being $[1,2,3]$.

The two psychological principles are why it is possible to buy only temporary happiness for a large amount of money for everyone except the very poor, and why our feelings are so great.i explains that they look like they are attached to a rubber thread that pulls them back, preventing them from flying or falling. Each of these principles is based on the assumption that happiness is a relative concept.

The phenomenon of the level of adaptation describes the trend of our reflection on various motivating factors related to events we have experienced in the past. As psychologist Harry Helson explains, each person determines a level of neutrality based on their experience soundneither high nor low points; temperature - neither hot nor cold; events - neither pleasant nor unpleasant. And then when this neutral level changes up and down, he feels it and pays attention to them.

So, if our income or social status exceeds the average point, we will initially feel a flow of well-being. Then we adjust to a new level of 
accomplishment, begin to consider it normal, and begin to demand more to feel the next stream of happiness. I remember as a child enjoying watching the first 12 -inch $(30 \mathrm{~cm})$ black and white TV in our family. Now if the 25inch $(62.5 \mathrm{~cm})$ TV loses color, I'm dissatisfied with somethingl feel like As the level of adaptation increases, I now think what I used to think was good is now bad. Yesterday's luxury is becoming the norm today. It is important to remember that peace and hate, luck and misfortune - all of these are relative compared to past experiences. So, can we ever create a lifelong social paradise on earth? Donald Campbell; no; answers: if you are in your own fantasy tomorrow - money, when you wake up where there are no illnesses, where everything is perfect, where there is someone who loves you faithfully - you will feel euphoria for a while. But quickly re-adjusting the level of adaptation, and again when you sometimes have more success than you expect, sometimes you start to feel the loss, and sometimes you start to feel neutral if your success does not live up to your expectations.

That's why we have the tragedy of lottery winners and paraplegic who have won millions of dollarsnevertheless, it helps to understand what they both say about the same level of happiness. This again explains why there are no material requirements, why many children need only one Nintendo game, and why Imelda Marcos, who grew up in poverty and lived in luxury, bought 1,060 pairs of shoes when she was the wife of the Philippine president. allows You are one of the winnersa enters and the person's property takes over, the degree of adaptation goes out of control $[2,3,4]$.

Happiness associated with children depends on such factors as a person's fertility, infertility, life of children at different ages, their health, education, achievements, satisfaction with them, its periodicity, variability. The main factor in this is that children grow up to be perfect people and live a happy life under the guidance of their parents.

A child means "a woman's happiness." When you look at life, you often see how real it is.

Often love childrenbrings into the world. For many people, the most patient part of this life change is a happy event. In a national survey, 93 percent of American mothers said, "I feel in my children the innumerable love I don't feel in anything else." Many fathers feel the same way. A few weeks after the birth of my first child, I was amazed at this realization: this was how my parents would feel about me. " $[1,3]$.

So all the work, our concern is to make our children happya tool. The main goal is the happiness of our sons and daughters.

Comparisons with others include comparing oneself to the rich, the poor, the learned, the ignorant, the polite, the rude, the disrespectful, the disrespectful, in many respects equal to oneself, in some respects superior or inferior, and so on. Happiness is not only relative to our past experience, but also relative to other people. We always compare ourselves to someone. Whether we feel good or badit depends on who the people are. When the people around us are low-spirited and awkward, we become more agile and smarter than them, and as a result, we begin to feel selfsatisfied. This, in turn, leads to a flow of feelings of happiness.

Similar comparisons tell us why people in a particular country who compare themselves to relatively poor, middle- and high-income people are more satisfied with their lives than their more unfortunate neighbors. 
Nevertheless, human well-beingg while having a moderate level, the subsequent increase in well-being has little effect on the increase in happiness. Why? Because, after achieving a certain level of success, they basically compare themselves to a person who is at their level or higher in status and material well-being than themselves.

So we are worse than the people we compare ourselves to, which leads to negative emotions. For the average person, the salaries of athletes have no emotional significance. "Poor people don't envy millionaires, but they do envy poor people who are more fortunate than themselves," said Bertrand Russell. That is why Napoleon was jealous of Caesar, Caesar was jealous of Alexander, and Alexander, I dare guess, was jealous of Hercules, who never existed. It follows that you can escape jealousy only through successyou can not, because in an event or legend there is always a luckier person than you;.

When we compare ourselves to unhappy people; when we count our wealth; we can increase our self-satisfaction. While comparing oneself with richer people is jealous, comparing oneself with poorer people brings joy. Marshall Dermer demonstrated this with his colleagues as follows. They are concerned about the poverty of people other than students at the University of Milwaukee in Wisconsin ca asked to observe their suffering. After looking at or imagining vivid images of how colorless life was in Milwaukee in 1900, and then describing various personal tragedies, such as how they were burned and their bodies turned ugly, the girls expressed how happy they were with their lives. Similarly, people who are in a moderate mood feel better when they read about people who are in a worse mood than they are.; Ourour poverty becomes a reality because it's not that we have less, it's that our neighbors have more; said Will Campbell.

Job satisfaction is determined by the level of interest, ability, skill, knowledge, skills, qualifications, productivity, efficiency and interest in it.

An individual's labor activity can be divided into two types: professional labor and voluntary, amateur, and amateur labor. With the quality inherent in both types of activityr The labor of the combined type of activity will be the labor activity that produces the highest satisfaction. As a result, we begin to feel happy.

The level of satisfaction with friends and communication depends on whether the qualities of friends are compatible with each other or their level of mutual compatibility. These are the basic conditions for building and maintaining friendships. Some people are always cheerful, while others get darker by the day. What makes one person happy and another less so?

While working or relaxing, most of us enjoy a fun complex activity. For example, people with mental work or active recreationthey feel happier when they are busy than when they sit idle in a passive state. For example, the cheaper and usually more fun a vacation is, the more uplifting the vacationers felt. Also, people feel happier when they are busy in their backyard or chatting with friends than when they are sitting in front of the TV. Happy teens have personal accomplishments and close relationships with regard to material possessions and prestigea are more prone. It can be concluded that the person whose work, leisure and friendships have completely occupied them and whose chosen activities allow them to feel positive emotions is happy. 
The above factors and relationships that lead to satisfaction, satisfaction, affect our happiness, but within the boundaries of the genetic chain. In a study of 254 twins, David Likken and Auk Tellegen concluded that a 50 percent difference in happiness levels is inherited.depending on. Even twins who grow up together and are not big can often feel the same amount of happiness. Depending on our views and the experience we have gained, our happiness; the point of testing it; swaying around. This point puts some in a good mood and others in a bad mood.

\section{CONCLUSION}

In addition to the above, there are certain conditions for satisfaction from many other factors in life. Satisfaction with all or some of these factors. The presence of sh and other life events constitute a life situation that determines the level of happiness for everyone. In conclusion, human happiness is determined by the degree of its adaptation to life factors. This level of adaptation is relatively variable. From this, a person's sense of happiness, along with the degree of satisfaction with his profession, work, family, children, living and working environment, social protection and other similar factors, his knowledge,it is clear that faith depends on having high spirituality and ideological immunity.

\section{REFERENCES}

1. Myers D. G. Psychology. Hope College. Holland, Michigan, 2010. - R. 910.

2. Goziev E.G'. General Psychology. Tashkent 2010.

3. Lykken, D. T., \& Tellegen, A. (1993) Is human mating adventitious or the result of lawful choice? A twin study of mate selection. Journal of Personality and Social Psychology, 65, 56-68. (p. 217)

4. Bolger, N., DeLongis, A., Kessler, R. C., \& Schilling, E. A. (1989). Effects of daily stress on negative mood. Journal of Personality and Social Psychology, 57, 808-818. (p. 520).

5. Shomirzayev, M.Kh. (2019). The ethical characterics of traditional embroidery of Fergana valley people. European Journal of Research and Reflection in Educational Sciences, 7 (12). - P. 55-59.

6. Shomirzayev, M.Kh. (2019). Ethnic peculiarities of artistic embroidery of the peoples of the Ferghana valley. European Journal of Research and Reflection in Educational Sciences. -7 (12). -P. 966-969.

7. Shomirzayev, M.Kh. (2019). Local features of the traditional embroidery of the Ferghana valley. European Journal of Research and Reflection in Educational Sciences. -7 (12). -P. 970973.

8. Shomirzayev, M.Kh. (2020). Education is personaly focused technology. European Journal of Research and Reflection in Educational Sciences, 8 (8), Part. 93-99.

9. Shomirzayev, M.Kh. et al. (2020). National handicrafts of Uzbekistan and its social - economic significance. European Journal of Research and Reflection in Educational Sciences, 8 (8), Part III. 129-138.

10. Shomirzayev, M.Kh. (July, 2020). Technology of Educational Process in School Technology Education. The American Journal of Social Science and Education Innovations. Impact Factor 5.366. $\quad$-№ $\quad 02 . \quad$-P. $212 \quad-223$. 
(www/usajournalshub.com/index.php/ tajssel).

11. Shomirzayev, M.Kh. (30 July, 2020). Developing Educational Technologles in School Technology Education. The American Journal of Social Science And Education Innovations, Impact Factor 5.26. $\quad$-P.II/VII $51 \quad-\quad 57$. (www/usajournalshub.com/index.php/ tajet).

12. Shomirzayev, M.Kh. The Concept Of Pedagogical Technology And Basic Principles. Academicia: An International Multidisciplinary Research Journal. (Affiliated to Kurukshetra University, Kurukshetra, India), Vol. 10, Issue 11, November 2020 Scientific Journal Impact Factor (Sjif 2020-7.13). $\quad$-Part 1554 - 1563. (https://saarj.com)

13. Shomirzayev, M.Kh. (2020). Ethnic characteristics of national traditional crafts. European Journal of Research and Reflection in Educational Sciences, 8 (12). - P. 216-225.

14. Shomirzayev, M.Kh. (2020). "Technology" In Secondary Schools Organization of Science Classes. The American Journal of Social Science and Education Innovations, Impact Factor 5.525 (11). -P. 395-405. (www/usajournalshub.com/index.php/ tajet).

15. Sharafutdinova, Kh.G. (2020). Destruktion of family pelations psychoprorkophylaxis family neighborhood educational institution. South Asian Academic Research Journals South Asian Academic Research Journals -ISSN: 2249-7137. Vol. 10 Issue 11, November 2020 Impact Factor: SJIF $2020=7.13 \cdot$ p 1005-1012.
16. Шомирзаев М.Х. Технология фанини ўқитишда инновацион педагогик технологиялар. Дарслик. -Т.: Тафаккур, 2021. -226 б.

17. Шомирзаев М.Х. Ўзбек миллий хунармандчилигининг шаклланиш генезиси ва ривожланиш технологияси. Ўқув-услубий қўлланма. -Т.: Yangi nashr, 2016.-88 б.

18. Шомирзаев М.Х. Ўзбек миллий хунармандчилигида инновацион жараёнлар. Ўқув-услубий қўлланма. T.: Yangi nashr, 2017. - 486.

19. Шомирзаев М.Х. Ўзбек миллий хунармандчилигининг спектралвариатив компонентлари. Ўқувуслубий қўлланма. - Т.: Yangi nashr, 2018. -48

20. Шомирзаев М.Х. Бойсун қуроқчилик санътини ўргатишда тарихий анъаналарнинг ўрни // Бойсун моддий ва номоддий маданияти бешиги" мавзусидаги Халқаро илмий-амалий конференцияси. - Т.: Yangi nashr, 2018. - Б.62-67.

21. Шомирзаев М.Х. Миллий

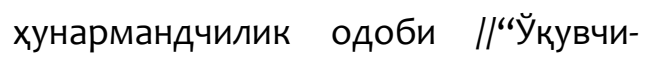
талаба креатив фаолиятини ривожлантиришда инновацион таълим технологиялари-дан фойдаланиш" мавзусидаги илмийуслубий мақолалар тўплами - Т.: Noshirlik yog'dusi, 2018. - Б.76-80.

22. Шомирзаев М.Х. Ўқувчиларга зардўзликда зар тикиш усулларини ўргатиш //“'Ўқувчи-талаба креатив фаолиятини ривожлантиришда иннова-цион таълим технологияларидан фойдаланиш" мавзусидаги илмий-услубий мақолалар тўплами. -Т.: Noshirlik yog'dusi, 2018. - Б. 195-198. 


\begin{tabular}{|c|c|}
\hline \multirow[t]{8}{*}{23.} & Шомирзаев M.X. Ўқувчиларга \\
\hline & зардўзлик хунарининг ривожланиш \\
\hline & тарихини ўргатиш //“Барқарор \\
\hline & ривожланишда узлуксиз таълим: \\
\hline & муаммо ва ечимлар” Халқаро илмий- \\
\hline & амалий анжуман илмий ишлар \\
\hline & тўплами. -Чирчиқ: Чирчиқ ДПИ, 2019. \\
\hline & $-5.380-382$. \\
\hline \multirow[t]{9}{*}{24.} & Ўқувчиларга \\
\hline & зардўзликда зар тикиш усулларини \\
\hline & ўргатиш // "Давр, замон, шахс" \\
\hline & цивилизациясида \\
\hline & бахшичилик санъатининг ўрни” \\
\hline & мавзусидаги халқаро илмий-амалий \\
\hline & конференцияси илмий мақолалари \\
\hline & тўплами. - Т.: Yangi nashr, 2019. - Б.195- \\
\hline & 198. \\
\hline \multirow[t]{5}{*}{25.} & Шомирзаев М.Х. Технология фанини \\
\hline & самарадорлигини \\
\hline & ошириш йўллари. Ўқув - методик \\
\hline & қўлланма. - T.: Gold print nashr, 2019. - \\
\hline & 566 \\
\hline
\end{tabular}

